\title{
CÉLULAS ELETROLÍTICA E A COMBUSTÍVEL CONFECCIONADAS COM MATERIAIS ALTERNATIVOS PARA O ENSINO DE ELETROQUÍMICA
}

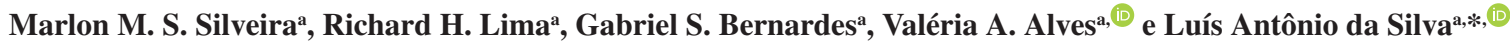 \\ aDepartamento de Química, Instituto de Ciências Exatas, Naturais e Educação/ICENE, Universidade Federal do Triângulo Mineiro, \\ 38064-200 Uberaba - MG, Brasil
}

Recebido em 20/12/2019; aceito em 15/07/2020; publicado na web em 02/09/2020

\begin{abstract}
ELECTROLYTIC AND FUEL CELLS MADE WITH ALTERNATIVE MATERIALS FOR THE TEACHING OF ELECTROCHEMISTRY. The proposal addresses the electrochemical experimentation as a pedagogical instrument for the integral and dynamic student involvement, facilitating the teaching-learning process. The experimental proposal focuses on the conversion of electrical energy to chemical energy and vice versa. The experiments for the two simultaneous energy conversions were designed with simple, easily accessible and inexpensive reagents and materials. The production of hydrogen and oxygen gases in the electrolytic cell, and the consumption of these same gases in the fuel cell, exploits the non-spontaneous and spontaneous electrochemical semireactions, respectively, that occur at the anode and cathode. Hydrogen gas production is crucial to the development of fuel cell technology. To facilitate the identification of anodic and cathodic reaction, and the monitoring of electrochemical decomposition of water, black bean extract was used as an alternative indicator. The electrochemical reactions involved in energy conversions are considered fundamental in the teaching-learning process of basic concepts related to water electrolysis and the recombination of hydrogen and oxygen gases. The experiment also corroborates the elucidation of alternative ways to generate electricity to meet the current needs of modern society.
\end{abstract}

Keywords: water electrolysis; fuel cell; alternative materials; electrochemical processes.

\section{INTRODUÇÃO}

Os primeiros estudos envolvendo a geração de correntes elétricas favoreceram o entendimento das reações eletroquímicas espontâneas que ocorrem quando dois metais diferentes são mergulhados numa solução eletrolítica. Para mostrar os avanços das descobertas, segue um relato bastante sintético de vários estudos realizados. As observações experimentais realizadas pelo filósofo natural John Walsh, entre 1772 e 1775, com peixes elétricos demonstraram a origem animal da eletricidade. Os estudos anatômicos e fisiológicos promoveram o progresso da fisiologia e da física dos fenômenos elétricos. ${ }^{1}$

O médico e cientista Luigi Galvani realizou descobertas a partir de experimentos envolvendo a aplicação de pequenas correntes elétricas em pernas de rã dessecadas, o que resultou em contrações musculares. Ele acreditava que a eletricidade era de origem animal, e os seus resultados foram publicados no livro De viribus electricitatis in motu musculari commentarius, em 1792. O físico e cientista Alessandro Volta, contemporâneo de Galvani, particularmente interessado pela eletricidade, havia publicado o seu primeiro tratado De vi attractiva ignis electrici, em 1778. Ele investigou os experimentos de Luigi Galvani e concluiu que o simples contato de metais de diferentes tipos resultava em pequenas correntes elétricas. Os estudos de Alessandro Volta foram fundamentais para a invenção da pilha elétrica. ${ }^{2}$

O químico e cientista John Frederic Daniell aperfeiçoou a pilha de Alessandro Volta. Daniell construiu um recipiente de cobre metálico contendo uma solução saturada de sulfato de cobre: dentro do recipiente de cobre encaixou um segundo recipiente de argila porosa contendo um eletrodo de zinco metálico mergulhado numa solução diluída de ácido sulfúrico. O recipiente poroso não permitia a mistura dos dois eletrólitos. As reações químicas eram controladas abrindo ou fechando o circuito elétrico entre os dois

*e-mail: luis.silva@uftm.edu.br metais. ${ }^{3}$ Em 1836 Daniell publicou uma carta endereçada a seu amigo Michael Faraday sobre as informações experimentais com o título On Voltaic Combinations. ${ }^{4}$

$\mathrm{O}$ conhecimento das propriedades eletroquímicas dos metais favoreceu o desenvolvimento das recentes tecnologias das baterias. As tecnologias dos celulares móveis e dos carros elétricos só foram possíveis com o desenvolvimento das baterias de íons lítio. As modernas baterias de íons lítio são tão importantes para a sociedade moderna que renderam o prêmio Nobel de Química de 2019 para os Químicos Akira Yoshino e Michael Stanley Whittingham, e o Físico John Bannister Goodenough. ${ }^{5}$

O estudo envolvendo gases na geração de corrente elétrica aconteceu após várias investigações com combinações de diferentes materiais metálicos. O advogado e cientista William Grove inventou a célula galvânica que funcionava com a combinação de dois gases diferentes. Cada gás era injetado separadamente no ânodo e no cátodo. Os eletrodos eram confeccionados com folhas de platina platinizada, possuindo grande área superficial. Os gases mantinham contatos com os eletrodos e com a solução eletrolítica, simultaneamente. $\mathrm{O}$ funcionamento da célula dependia do contato entre as três fases (gás, líquido e sólido). Considerando-se os gases hidrogênio e oxigênio, tem-se que a platina platinizada catalisa a reação de decomposição eletroquímica. Grove observou a importância da porosidade como superfície de ação entre as fases sólida, líquida e gasosa para efetivar as semirreações de oxidação do hidrogênio e redução do oxigênio. ${ }^{6}$ A descoberta de Grove, intitulada On Voltaic Series and the Combination of Gases by Platinum, foi publicada em 1838 no jornal Philosophical Magazine and Journal of Science. ${ }^{7}$ Grove chamou o seu invento de célula a combustível. ${ }^{8}$ Tem-se que uma célula a combustível é um tipo de célula galvânica, onde as reações eletroquímicas espontâneas ocorrem entre o cátodo (eletrodo onde ocorre a redução, polo positivo) e o ânodo (eletrodo onde ocorre a oxidação, polo negativo), convertendo energia química acumulada no sistema em energia elétrica. ${ }^{9}$ 
A crescente demanda por energia limpa tem promovido as pesquisas com células a combustíveis como procedimento de consumo de energia química armazenada, e também como fonte energética alternativa para os combustíveis fósseis. ${ }^{10} \mathrm{Na}$ geração de energia elétrica a partir dos combustíveis fósseis, que ocorre no Brasil em período de escassez de chuva, tem-se a emissão de grandes quantidades de gases poluentes e envolve três etapas, acompanhadas de sucessivas perdas de energia: $1^{\mathrm{a}}$ - a conversão de energia química em energia térmica; $2^{\mathrm{a}}$ - a conversão de energia térmica em energia mecânica; $3^{\mathrm{a}}$ - a conversão de energia mecânica em energia elétrica. ${ }^{11}$

As fontes de energia renovável, como solar, eólica e hidráulica, são intermitentes. A energia solar está disponível somente durante os dias ensolarados, o que coloca o Brasil numa posição de destaque; como exemplo, no extremo sul do país a duração do dia varia de 10 horas e 13 minutos a 13 horas e 47 minutos, aproximadamente, entre 21 de junho e 22 de dezembro, respectivamente. ${ }^{12,13}$ A energia eólica depende das condições climáticas sazonal anual. No Brasil, a região nordeste possui o maior potencial para a geração de energia eólica e também o maior número de centrais eólicas outorgadas. ${ }^{14,15} \mathrm{~A}$ quantidade de energia hidráulica disponível depende da topografia do relevo e da quantidade de chuva na bacia hidrográfica. O Brasil possui um dos maiores potenciais hidrelétricos do mundo, sendo também um dos maiores produtores e consumidores de energia hidráulica. ${ }^{16,17}$

O melhor aproveitamento da matriz energética está fortemente atrelado ao desenvolvimento de tecnologias de armazenamento de energia elétrica, o qual refere-se a um processo de conversão de energia elétrica em uma fonte energética que pode ser armazenada para consumo em momentos de escassez. Existem diversas tecnologias de armazenamento de energia, como por exemplo, mecânica (ar comprimido, bombeamento hidráulico), térmica (água aquecida), eletromagnética (bobina supercondutora), elétrica (super condutores), química e eletroquímica (hidrogênio, baterias). ${ }^{18,19}$ Considerando-se a produção do gás hidrogênio a partir da eletrólise da água, tem-se um processo não espontâneo que necessita de grandes quantidades de energia elétrica. A decomposição da água acontece numa célula eletrolítica a partir da aplicação de um potencial eletroquímico externo entre o cátodo (eletrodo onde ocorre a redução da água, polo negativo) e o ânodo (eletrodo onde ocorre a oxidação da água, polo positivo), convertendo energia elétrica em energia química. ${ }^{9}$

É frequente nas manchetes dos jornais as discussões em torno das questões ambientais relacionadas com as fontes energéticas. $\mathrm{O}$ momento é oportuno para a apresentação de conteúdos relacionados com as novas formas de geração de energia limpa, sem poluir o meio ambiente. Face ao exposto, nesse trabalho considerou-se a importância de disponibilizar experimentos de produção eletroquímica dos gases hidrogênio e oxigênio, contextualizando com as fontes alternativas de energia elétrica, como por exemplo eólicas, solares e hidráulicas, e tecnologias de armazenamento de energia elétrica, como estratégia para a formação plena do estudante, com relação ao conhecimento químico e também com respeito à sua formação cidadã, levando-o a refletir sobre questões ambientais e de sustentabilidade do planeta. ${ }^{20,21}$ Na sequência, os gases hidrogênio e oxigênio armazenados foram utilizados para alimentar células a combustível associadas em série. A geração da corrente elétrica foi comprovada com o funcionamento de um relógio digital de 1,5 V. A experimentação procurou fechar o ciclo da produção, armazenamento e consumo de energia limpa.

A química é uma ciência que se desenvolve sobre uma base experimental, onde as transformações químicas podem ser observadas, explicadas e reproduzidas. A experimentação desempenha um papel extremamente importante para o entendimento dos fenômenos químicos que ocorrem com a matéria, como por exemplo, a reação química espontânea de um ácido com uma base, a reação do $\mathrm{CO}_{2}$ com a $\mathrm{H}_{2} \mathrm{O}$ durante a fotossíntese, a liberação dos gases $\mathrm{H}_{2}$ e $\mathrm{O}_{2}$ durante a eletrólise da água, a reação que ocorre quando combinamos os metais zinco e cobre numa célula galvânica. Considerando-se o processo de ensino-aprendizagem, a experimentação na química favorece a articulação entre práticas e teorias, bem como conhecer as concepções prévias dos estudantes, frente aos novos conceitos que serão explorados. ${ }^{22,23}$

A experimentação é um componente indispensável para o processo de ensino-aprendizagem de conteúdos de química, facilita a compreensão de conceitos químicos e a aquisição de habilidades práticas. O planejamento e a execução experimental promovem o aprendizado de novos conceitos de química, novos procedimentos e atitudes dos estudantes, incentivando-os a participarem das discussões em sala de aula.

É bastante comum ouvir relatos de professores e estudantes do ensino médio e superior sobre as dificuldades com o processo de ensino-aprendizagem relacionados com o conteúdo de eletroquímica. ${ }^{24} \mathrm{Nesse}$ contexto, torna-se imperioso o desenvolvimento de experimentos que facilitem o entendimento das transformações eletroquímicas.

Uma pesquisa realizada nas revistas publicadas pela Sociedade Brasileira de Química, a partir do ano 2000, encontrou-se um pequeno número de publicações relacionado com células galvânicas (convencionais), eletrolíticas e a combustível. Considerando-se a célula a combustível uma situação particular da célula galvânica, porque envolve a manipulação de gases, os artigos encontrados fazem uma abordagem puramente teórica sobre essa tecnologia, não abordando a experimentação no ensino de eletroquímica, ${ }^{10,25}$ o que mostra a importância do presente trabalho.

O número de publicações com as células galvânicas e eletrolíticas é superior em relação àqueles envolvendo as células a combustível, o que provavelmente está relacionado com a facilidade em manipular soluções aquosas em relação aos gases utilizados nesta última. No caso das células galvânicas as reações eletroquímicas envolvendo a oxidação do zinco e a redução de cobre são frequentemente investigadas. ${ }^{26-32}$ Por outro lado, a eletrólise da água, ou mesmo a eletrodeposição de cobre ou prata sobre um cátodo são explorados nos estudos envolvendo as células eletrolíticas. ${ }^{20,21,33-35}$

Abordar o conteúdo de eletroquímica com os estudantes é muito importante para o entendimento de novas tecnologias relacionadas com a geração de energia elétrica. Os experimentos planejados com materiais de baixo custo e fácil acesso visam minimizar as dificuldades encontradas pelos professores e estudantes, no processo de ensinoaprendizagem de eletroquímica. ${ }^{22,24,26,36}$ As células eletrolítica e a combustível foram planejadas para utilização por professores, no seu processo de ensino de eletroquímica, para estudantes do ensino médio ou superior. A partir dos experimentos, os estudantes terão a oportunidade de compreender as reações eletroquímicas espontâneas e não espontâneas, observar as reações de desprendimento dos gases $\mathrm{H}_{2}$ e $\mathrm{O}_{2}$, as proporções volumétricas dos gases durante a eletrólise da água, a manipulação dos gases entre as duas células (eletrolítica e a combustível), e realizar observações úteis na compreensão dos conceitos relacionados com as semirreações de oxidação e de redução. É importante destacar no trabalho o arranjo experimental simples de produção e manipulação dos gases, não sendo necessário o uso de instrumentação específica.

\section{PARTE EXPERIMENTAL}

Os experimentos foram executados no laboratório de química do Departamento de Química da UFTM, e contou com a participação de dois estudantes de graduação do curso de Licenciatura em Química e de um professor do ensino básico cursando o Mestrado Profissional em Química em Rede Nacional (PROFQUI), sendo o trabalho em 
apreço o produto educacional de sua dissertação de mestrado. A participação dos dois estudantes na realização dos experimentos foi fundamental para as adequações e testes de funcionamento das células eletrolítica e a combustível, além de contribuir com o professor que possui dois cargos em duas escolas estaduais do estado de Minas Gerais, e viaja $400 \mathrm{~km}$ toda semana de Paranaíba (MS) para Uberaba (MG) para cursar o mestrado. O presente produto educacional foi aplicado pelo professor em duas turmas de estudantes do $2^{\circ}$ ano do ensino médio de uma escola estadual localizada no município de União de Minas (MG), pertencente a Superintendência Regional de Ensino de Uberaba (MG). Os resultados obtidos ainda não foram publicados.

O trabalho foi dividido em duas etapas: a primeira correspondendo à construção e o funcionamento de uma célula eletrolítica, kit $\mathrm{A}$; e a segunda, correspondendo à construção e o funcionamento de uma célula a combustível, kit $\mathrm{B}$.

\section{Kit A - célula eletrolítica}

\section{Materiais necessários para o kit A}

- Duas chapas retangulares de aço inoxidável austenítico, tipo AISI $306 \mathrm{~L}$, medindo 2,0 cm de largura, 3,0 cm de comprimento, 0,5 mm de espessura e uma rebarba de $1,0 \mathrm{~cm}$ de comprimento;

- Dois pedaços de fios de cobre flexíveis encapados medindo 3,0 mm de diâmetro e $10 \mathrm{~cm}$ de comprimento;

- Duas seringas descartáveis de $60 \mathrm{~mL}$;

- Duas seringas descartáveis de $20 \mathrm{~mL}$;

- Dois escalpes utilizados para infusões venosas;

- Um pote de plástico transparente de $500 \mathrm{~mL}$ com tampa;

- Duas agulhas medindo $40 \times 1,2 \mathrm{~mm}$;

- Duas presilhas para crachá;

- Um metro de mangueira siliconada para bomba de aquário de 5,0 mm de diâmetro;

- Resina epóxi;

- $200 \mathrm{~mL}$ de solução de $\mathrm{H}_{2} \mathrm{SO}_{4} 0,5 \mathrm{~mol} \mathrm{~L}^{-1}$;

- 70 g de feijão preto;

- Papel tornassol;

- Ferro de solda;

- Estanho em fio para solda;

- Uma fonte elétrica de $12 \mathrm{~V}$ e $1 \mathrm{~A}$.

\section{Montagem do kit $A$}

Para a construção dos eletrodos da célula eletrolítica, primeiro fez-se uma canaleta em cada rebarba das chapas de aço inoxidável austenítico para o contato elétrico, em seguida desencapou-se $1,0 \mathrm{~cm}$ do plástico nos dois pedaços de fios de cobre flexíveis, encaixou-se na canaleta e aplicou-se a solda. $\mathrm{O}$ conjunto foi encaixado no interior de uma mangueira siliconada de 5,0 mm de diâmetro, vedou-se o contato elétrico com resina epóxi e aguardou-se 90 minutos para secar.
Em seguida, removeu-se os êmbolos das duas seringas descartáveis de $60 \mathrm{~mL}$, fez-se um pequeno furo de 5,0 $\mathrm{mm}$ de diâmetro ao lado do orifício de encaixe da agulha em cada seringa, encaixou-se os eletrodos de aço inoxidável austenítico, fixou-se, vedou-se com resina epóxi e aguardou-se 90 minutos para secar. Para facilitar o preenchimento das seringas com o eletrólito e aspiração dos gases hidrogênio e oxigênio, cortou-se a ponta do tubo flexível de dois escalpes para remover os corpos das asas e agulhas, rosqueou-se um escalpe em cada seringa. Os dois eletrodos montados foram colocados no pote de plástico de $500 \mathrm{~mL}$ e encaixados de forma segura na tampa, para garantir a verticalidade das seringas antes do preenchimento com o eletrólito. Os materiais e a montagem da célula eletrolítica podem ser vistos na Figura 1.

Para aspirar o eletrólito e preencher o interior das seringas montadas com os eletrodos, usou-se duas seringas descartáveis de $20 \mathrm{~mL}$ e rosqueou-se em cada seringa uma agulha medindo $40 \times 1,2 \mathrm{~mm}$. Importante remover o corte oblíquo em aresta das agulhas (bisel) para evitar acidentes. Para abertura e fechamento dos tubos flexíveis dos escalpes, usou-se presilhas para crachá.

A solução de $\mathrm{H}_{2} \mathrm{SO}_{4} 0,5 \mathrm{~mol} \mathrm{~L}^{-1}$ foi preparada com ácido sulfúrico $98 \%$ de pureza. O extrato de feijão preto foi preparado misturando-se $\sim 70 \mathrm{~g}$ de feijão preto (uma xícara de café), com $200 \mathrm{~mL}$ de solução de $\mathrm{H}_{2} \mathrm{SO}_{4}$ 0,5 mol L ${ }^{-1}$ num pote descartável de plástico de $500 \mathrm{~mL}$. Após 10 minutos separou-se os grãos de feijão da solução ácida vermelha. Essa solução vermelha consistiu no eletrólito usado na célula eletrolítica. $\mathrm{O}$ extrato de feijão preto atuou como indicador alternativo de $\mathrm{pH} \cdot{ }^{37}$

No pote de plástico contendo $200 \mathrm{~mL}$ da solução vermelha de $\mathrm{H}_{2} \mathrm{SO}_{4} 0,5 \mathrm{~mol} \mathrm{~L}^{-1}$, posicionou-se verticalmente as duas seringas de $60 \mathrm{~mL}$ contendo os eletrodos de aço inoxidável austenítico. Em seguida, conectou-se nos escalpes das duas seringas de $60 \mathrm{~mL}$ as agulhas das outras duas seringas de $20 \mathrm{~mL}$, para o preenchimento completo com a solução eletrolítica vermelha de $\mathrm{H}_{2} \mathrm{SO}_{4} 0,5 \mathrm{~mol} \mathrm{~L}{ }^{-1}$. Após preenchimento das seringas de $60 \mathrm{~mL}$, utilizou-se as presilhas para crachá como braçadeiras para obstruir os tubos flexíveis dos escalpes. Desconectou-se as duas seringas de $20 \mathrm{~mL}$, dispensou-se o ar aspirado e conectou-se novamente, para posterior aspiração dos gases hidrogênio e oxigênio produzidos pela eletrólise da água. Em seguida, conectou-se o polo negativo da fonte elétrica no cátodo (redução da água e produção do gás hidrogênio) e o polo positivo da fonte elétrica no ânodo (oxidação da água e produção do gás oxigênio). Conectou-se a fonte elétrica na rede elétrica e iniciaramse as semirreações de desprendimento de hidrogênio e oxigênio. Após produção de aproximadamente $20 \mathrm{~mL}$ do gás hidrogênio e $10 \mathrm{~mL}$ do gás oxigênio, os gases foram coletados usando-se as seringas de $20 \mathrm{~mL}$ que estavam conectadas nos escalpes. Utilizou-se novamente as presilhas para crachá como braçadeiras para obstruir os tubos flexíveis dos escalpes, e desconectou-se da célula eletrolítica as duas seringas de $20 \mathrm{~mL}$ contendo os gases

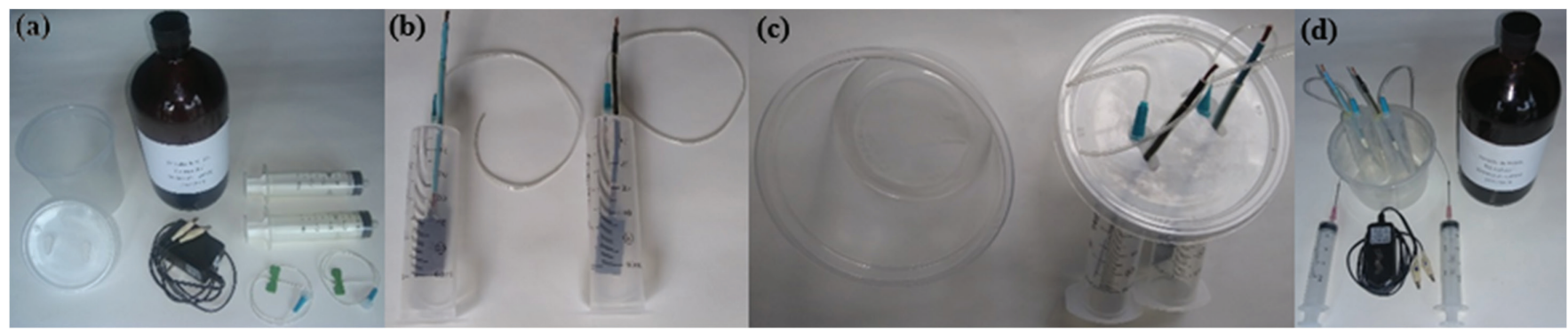

Figura 1. (a) Materiais utilizados na montagem da célula eletrolítica; (b) eletrodos de aço inoxidável austenítico montados dentro das seringas de 60 mL; (c) detalhe na tampa do pote de plástico para encaixe e estabilidade das seringas na posição vertical; (d) conexões das seringas de $20 \mathrm{~mL}$ para o preenchimento total dos eletrodos 
hidrogênio e oxigênio. Esses gases coletados foram usados na célula a combustível.

\section{Materiais alternativos para o kit A}

Retalhos de aço inoxidável austenítico, tipo AISI 306L, são descartados e facilmente encontrados nas indústrias de fabricação de utensílios domésticos, como por exemplo, bebedouros. Os fios de cobre são facilmente encontrados em sobras de instalações elétricas domésticas. As seringas descartáveis, os escalpes e as agulhas podem ser encontrados nas farmácias ou lojas de produtos agropecuários. Um béquer de vidro com capacidade para $500 \mathrm{~mL}$ poderá ser substituído por um pote de plástico. Braçadeiras de tubulação com parafuso Hoffman poderão ser substituídas por presilhas para crachá. Soda cáustica, $\mathrm{NaOH}$, comercializada nos supermercados, poderá substituir o ácido sulfúrico, $\mathrm{H}_{2} \mathrm{SO}_{4}$. $\mathrm{O}$ extrato de feijão preto poderá ser utilizado com a solução de $\mathrm{NaOH}$. O procedimento de preparação do extrato de feijão preto será o mesmo daquele preparado com o $\mathrm{H}_{2} \mathrm{SO}_{4}$, bastando substituir o ácido sulfúrico por soda cáustica $1,0 \mathrm{~mol} \mathrm{~L}^{-1}$, o que resultará numa solução amarela. A fonte elétrica pode ser encontrada em lojas de materiais eletrônicos, ou reaproveitadas de fontes elétricas usadas, de celulares.

\section{Kit B - célula a combustível}

\section{Materiais necessários para o kit B}

- Quatro pedaços de fio de platina medindo 0,25 mm de diâmetro, $10,0 \mathrm{~cm}$ de comprimento e $99,95 \%$ de pureza;

- Quatro pedaços de fios de cobre maciços desencapados medindo $1,0 \mathrm{~mm}$ de diâmetro e $6,0 \mathrm{~cm}$ de comprimento;

- Quatro tubos de vidro de 2,0 mm de diâmetro interno e 5,0 cm de comprimento;

- Quatro seringas descartáveis de $10 \mathrm{~mL}$;

- Quatro seringas descartáveis de $20 \mathrm{~mL}$;

- Quatro escalpes utilizados para infusões venosas;

- Quatro agulhas medindo $40 \times 1,20 \mathrm{~mm}$;

- Dois potes de plástico de $250 \mathrm{~mL}$ com tampa;

- Quatro presilhas para crachá;

- Resina epóxi;

- $200 \mathrm{~mL}$ de solução de $\mathrm{H}_{2} \mathrm{SO}_{4} 0,5 \mathrm{~mol} \mathrm{~L}{ }^{-1}$;

- 70 g de feijão preto;

- Papel tornassol;

- Ferro de solda;

- Estanho em fio para solda;

- Um multímetro digital;

- Um relógio digital que necessita de uma pilha de 1,5 V.

\section{Montagem do kit $B$}

Nesse trabalho utilizou-se fios de platina em espiral como ânodo (polo negativo) e cátodo (polo positivo) da célula a combustível, similarmente à descrição da célula a combustível de Grove. . $^{7,83}$
A platina apresenta alta atividade eletrocatalítica para as duas semirreações, oxidação do $\mathrm{H}_{2}$ e redução do $\mathrm{O}_{2}$, e é quimicamente estável, inertes, nas condições do experimento. ${ }^{39}$

A confecção de quatro eletrodos para as duas células a combustível iniciou-se com o preparo de quatro espirais de platina. As espirais medindo 3,0 $\mathrm{mm}$ de diâmetro interno e $\sim 3,0 \mathrm{~cm}$ de comprimento foram soldadas nos fios de cobre maciços para os contatos elétricos. Em seguida, introduziu-se cada fio de cobre nos orifícios de cada tubo capilar de vidro, deixando expostos de um lado do tubo capilar as espirais de platina, e do outro lado do tubo capilar uma ponta do fio de cobre de $1,0 \mathrm{~cm}$ de comprimento, para o contato elétrico. A solda e as duas extremidades de cada tubo capilar de vidro contendo o eletrodo de platina foram vedadas com resina epóxi, e aguardou-se 90 minutos para secar. Em seguida, removeuse os êmbolos das quatro seringas descartáveis de $10 \mathrm{~mL}$, fez-se um pequeno furo de 3,0 mm de diâmetro ao lado do orifício de encaixe da agulha em cada seringa, encaixou-se os eletrodos de platina, fixou-se e vedou-se com resina epóxi, e aguardou-se 90 minutos para secar. Para facilitar o preenchimento das seringas com o eletrólito e depois fazer a injeção dos gases hidrogênio e oxigênio, cortou-se a ponta do tubo flexível de quatro escalpes para remover os corpos das asas e agulhas, rosqueou-se um escalpe em cada seringa $10 \mathrm{~mL}$ e encaixou-se em cada escalpe uma agulha medindo $40 \times 1,2 \mathrm{~mm}$. Importante remover o corte oblíquo em aresta de cada agulha (bisel) para evitar acidentes. Os quatro eletrodos montados foram colocados no pote de plástico de $250 \mathrm{~mL}$ e encaixados de forma segura na tampa, para garantir a verticalidade das seringas antes do preenchimento com o eletrólito. Foram preparadas duas células a combustível, para posterior associação em série. Os materiais e a montagem da célula a combustível podem ser vistos na Figura 2.

Para aspirar o eletrólito e preencher as quatro seringas de $10 \mathrm{~mL}$ montadas com os eletrodos de platina, separou-se quatro seringas descartáveis de $20 \mathrm{~mL}$. Para o funcionamento do relógio digital com a célula a combustível providenciou-se novos contatos elétricos com dois fios de cobre finos e flexíveis. Primeiro soldou-se uma garra jacaré pequena em cada fio, depois abriu-se o relógio e efetuou-se a solda de um fio no polo negativo e do outro fio no polo positivo do suporte para a pilha de 1,5 V. O extrato de feijão preto foi preparado seguindo o mesmo procedimento já descrito anteriormente, para o kit $\mathrm{A}$.

Em seguida, conectou-se as agulhas, montadas nas quatro seringas de $10 \mathrm{~mL}$, às quatro seringas de $20 \mathrm{~mL}$ e aspirou-se a solução eletrolítica vermelha de $\mathrm{H}_{2} \mathrm{SO}_{4} 0,5 \mathrm{~mol} \mathrm{~L}^{-1}$. Após preenchimento das quatro seringas de $10 \mathrm{~mL}$, utilizou-se as presilhas para crachá como braçadeiras para obstruir os tubos flexíveis dos escalpes. Desconectouse as quatro seringas de $20 \mathrm{~mL}$, dispensou-se o ar aspirado e conectouse as seringas contendo os gases hidrogênio e oxigênio produzidos pela eletrólise da água. Injetou-se $10 \mathrm{~mL}$ de gás hidrogênio no ânodo (polo negativo) de cada célula a combustível e $5 \mathrm{~mL}$ de gás oxigênio no cátodo (polo positivo) de cada célula a combustível.

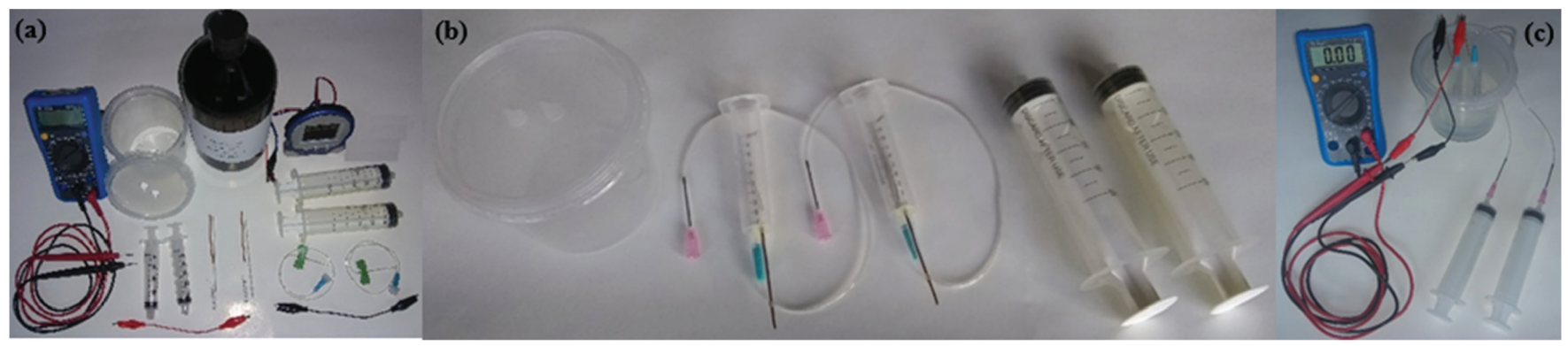

Figura 2. (a) Materiais utilizados na montagem das células a combustível; (b) eletrodos de platina montados dentro das seringas de 10 mL; (c) conexões das seringas de $20 \mathrm{~mL}$ para o preenchimento total dos eletrodos 
Mediu-se o potencial de cada célula a combustível separadamente, e depois das duas células a combustível associadas em série, utilizandose um multímetro digital ajustado na escala de $20 \mathrm{~V}$. No primeiro caso, conectou-se o cabo preto do multímetro no polo negativo (ânodo) da célula a combustível e o cabo vermelho do multímetro no polo positivo (cátodo) da célula a combustível. A associação em série das células a combustível foi realizada conectando-se o ânodo (polo negativo) da primeira célula a combustível ao cátodo (polo positivo) da segunda célula a combustível. Para a medida do potencial, conectou-se o cabo vermelho do multímetro no polo positivo (cátodo) da primeira célula a combustível e o cabo preto do multímetro no polo negativo (ânodo) da segunda célula a combustível.

Para ilustrar o funcionamento da célula a combustível utilizou-se um relógio digital que necessita de uma pilha de 1,5 V. Primeiro as duas células a combustível foram associadas em série e, em seguida, ligou-se o polo negativo do relógio digital ao polo negativo (ânodo) da célula a combustível; em seguida, ligou o polo positivo do relógio digital ao polo positivo (cátodo) da célula a combustível. ${ }^{21}$

\section{Materiais alternativos para o kit B}

Os fios de platina utilizados neste trabalho foram recebidos como doação. Não foi possível conseguir outros metais ou ligas metálicas com as características eletrocatalíticas da platina. O tubo de vidro poderá ser substituído por um tubo capilar para micro-hematócrito. Um béquer de vidro com capacidade para $250 \mathrm{~mL}$ poderá ser substituído por um pote de plástico. Um multímetro bem simples pode ser adquirido facilmente em lojas de materiais elétricos, por menos de $\mathrm{R} \$ 30,00$. A confirmação do potencial poderá ser feita também com o funcionamento do relógio digital ou acender uma lâmpada led (diodo emissor de luz). Os outros materiais foram descritos no item materiais alternativos para o kit $\mathrm{A}$.

\section{RESULTADOS E DISCUSSÃO}

\section{Kit A - célula eletrolítica}

Comportamento do extrato de feijão preto durante a eletrólise da água em solução ácida

O extrato de feijão preto é utilizado como um indicador ácido-base alternativo. Os principais componentes do extrato de feijão preto são as antocianinas, que são compostos fenólicos pertencentes ao grupo dos flavonóides. As cores observadas do extrato estão relacionadas com as substâncias que compõem o subgrupo das antocianinas, sendo que as duas principais substâncias são a delfinidina e a pelargonidina. Alterações na estrutura dessas antocianinas são responsáveis pela mudança de cor quando se altera o $\mathrm{pH}$ do meio. ${ }^{37,40,41}$ Em solução ácida, o extrato de feijão preto apresenta coloração vermelha e, em solução básica, a coloração amarela.

A solução de $\mathrm{H}_{2} \mathrm{SO}_{4} 0,5 \mathrm{~mol} \mathrm{~L}^{-1}$ recém preparada com o extrato de feijão preto apresentou a cor vermelha $(\mathrm{pH} \cong 0,30)$. Durante todo o tempo de eletrólise da água não se observou alteração da cor da solução do cátodo (polo negativo). Já na seringa contendo o ânodo (polo positivo) a cor da solução mudou para amarela, Figura 3. Medidas de pH com papel tornassol das soluções do cátodo e do ânodo, após eletrólise, comprovaram o caráter ácido das mesmas. Nesse caso, a mudança de cor da solução do ânodo provavelmente está relacionada com a oxidação eletroquímica da delfinidina e/ou da pelargonidina. ${ }^{42}$ A possível ocorrência de uma reação paralela de oxidação das antocianinas não interferiu na eletrólise da água e na pureza dos gases produzidos.

Produção dos gases hidrogênio e oxigênio em solução ácida

Considerando-se a produção dos gases hidrogênio e oxigênio

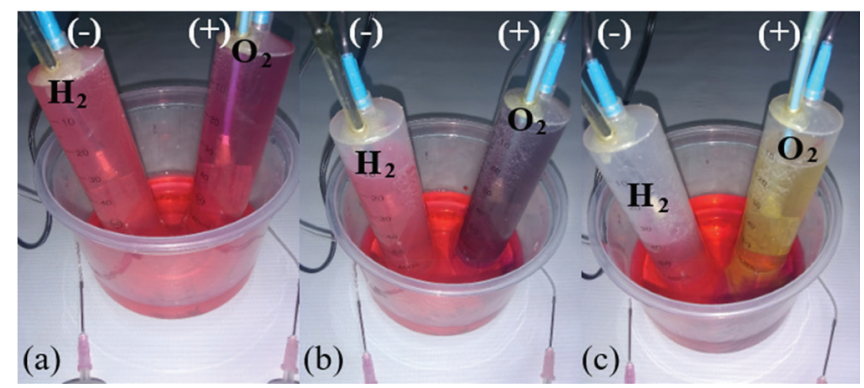

Figura 3. Eletrólise da água utilizando como solução eletrolítica a mistura de $\mathrm{H}_{2} \mathrm{SO}_{4} 0,5$ mol $\mathrm{L}^{-1}$ com extrato de feijão preto. (a) Início da eletrólise; (b) após 1 minuto de eletrólise; (c) após 5 minutos de eletrólise

numa célula eletrolítica, o processo ocorre por meio da transformação de energia elétrica em energia química, e os gases assim produzidos possuem alto grau de pureza. Utilizou-se o extrato de feijão preto para destacar a solução eletrolítica ácida e melhorar a visibilidade das semirreações de desprendimento dos gases hidrogênio e oxigênio, Figuras 4(a), 4(b) e 4(c). A Figura 4(d) apresenta o detalhamento da eletrólise da água na célula eletrolítica contendo a mistura de $\mathrm{H}_{2} \mathrm{SO}_{4}$ $0,5 \mathrm{~mol} \mathrm{~L}^{-1}$ com extrato de feijão preto, o que facilita o entendimento das semirreações eletroquímicas de produção dos gases hidrogênio e oxigênio. Manteve-se o sistema aberto e observou-se que o volume do gás hidrogênio é o dobro do volume do gás oxigênio, concordando com a estequiometria da reação para a formação da água.

As semirreações que estão ocorrendo no ânodo e no cátodo da célula eletrolítica podem ser expressas por meio de equações químicas. Escrever as semirreações e correlacioná-las com os respectivos potenciais nas condições padrão é o modo para saber se a reação eletroquímica será espontânea ou não. Considerando-se a produção dos gases hidrogênio e oxigênio em solução ácida, mostrada nas Figuras 4(c) e (d), pode-se escrever as equações químicas (1) e (2).

O potencial aplicado nos eletrodos imersos na solução eletrolítica favoreceu a ocorrência da reação não espontânea de decomposição da água. No polo negativo (cátodo) iniciou-se a semirreação de desprendimento de hidrogênio, equação química (1), e no polo positivo (ânodo) a semirreação de desprendimento de oxigênio, equação química (2), e a reação global, equação química (3). Detalhes das semirreações eletroquímicas nas condições padrão (1 bar, $1 \mathrm{~mol} \mathrm{~L}^{-1}$ e $298,15 \mathrm{~K}$ ) em solução ácida encontram-se no texto e nas Tabelas 1S, 2S e 3S do Material Suplementar.

cátodo: $4 H^{+}{ }_{(a q)}+4 e^{-} \rightarrow 2 H_{2(g)}$

ânodo: $2 \mathrm{H}_{2} \mathrm{O}_{(l)} \rightarrow \mathrm{O}_{2(g)}+4 H_{(a q)}^{+}+4 e^{-}$

reação global: $2 \mathrm{H}_{2} \mathrm{O}_{(l)} \rightarrow \mathrm{O}_{2(g)}+2 \mathrm{H}_{2(g)}$

Comportamento do extrato de feijão preto durante a eletrólise da água em solução básica

Diferentemente da solução ácida, a solução de $\mathrm{NaOH}$ 1,0 mol L-1 recém preparada com o extrato de feijão preto apresentou a cor amarela $(\mathrm{pH} \cong 14,00)$. Durante a eletrólise da água não houve nenhuma alteração da cor da solução básica em ambas as seringas, mas observou-se a formação de espuma por causa do extrato de feijão

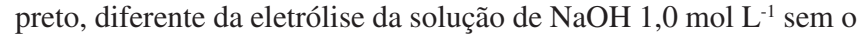
extrato, Figura 5. Medidas de pH com papel tornassol, após eletrólise, comprovaram o caráter básico da solução nas duas seringas.

Produção dos gases hidrogênio e oxigênio em solução básica

$\mathrm{O}$ indicador alternativo de $\mathrm{pH}$ foi usado para melhorar a visibilidade das semirreações de desprendimento dos gases hidrogênio e oxigênio e para facilitar a leitura dos volumes dos gases, Figuras 6(a), 6(b) e 6(c). A Figura 6(d) apresenta o esquema 

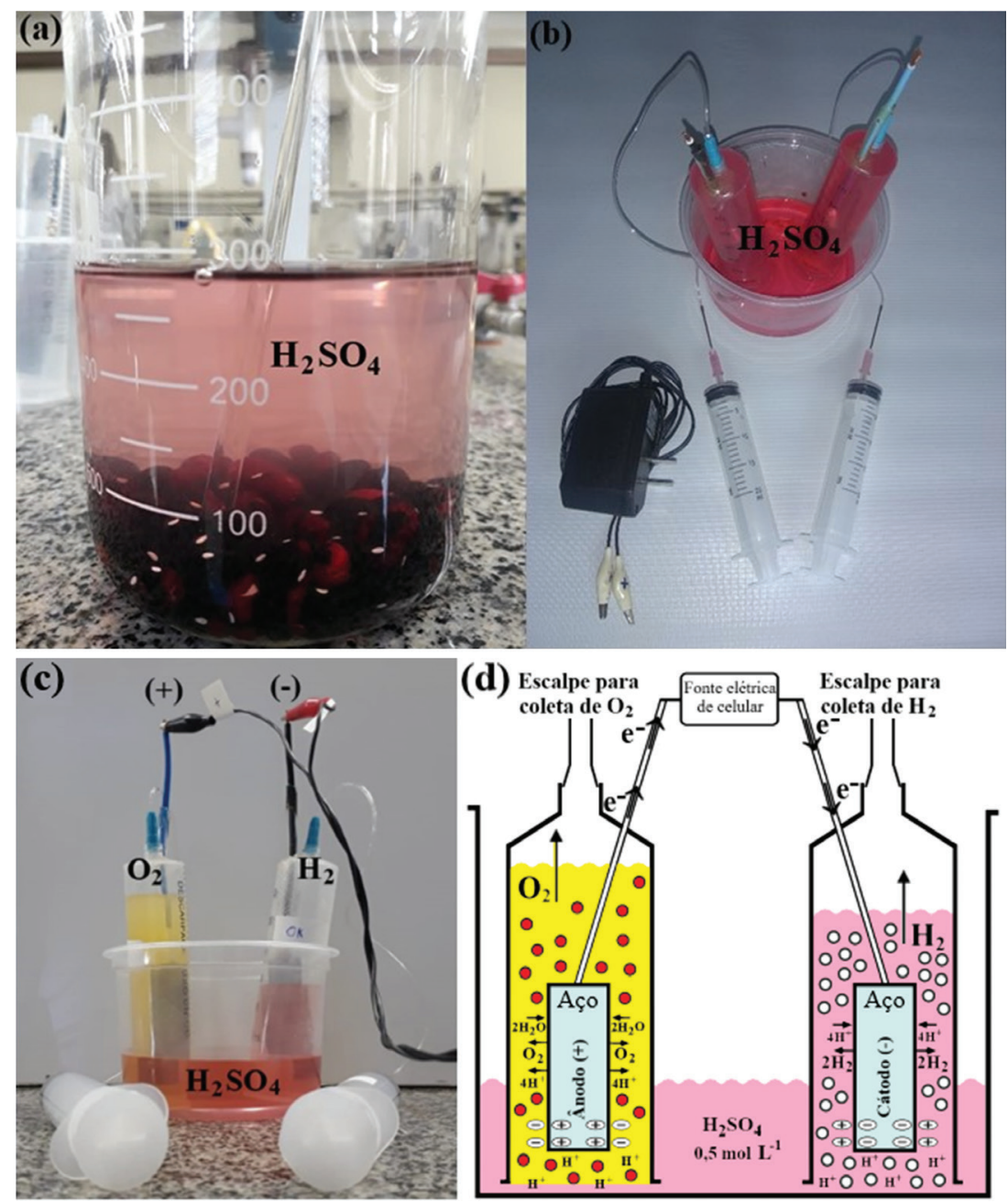

Figura 4. (a) Mistura da solução eletrolítica de $\mathrm{H}_{2} \mathrm{SO}_{4} 0,5$ mol L $L^{-1}$ com feijão preto para extração das antocianinas; (b) preenchimento das seringas com a mistura de $\mathrm{H}_{2} \mathrm{SO}_{4} 0,5 \mathrm{~mol} \mathrm{~L} \mathrm{~L}^{-1}$ com extrato de feijão preto; (c) eletrólise da água e desprendimento de $\mathrm{H}_{2}$ no cátodo (-) e de $\mathrm{O}_{2}$ no ânodo (+); (d) esquema detalhando as espécies envolvidas na eletrólise da água em solução ácida, $\mathrm{H}_{2} \mathrm{SO}_{4} \mathrm{O}, 5 \mathrm{~mol} \mathrm{~L}^{-1}$

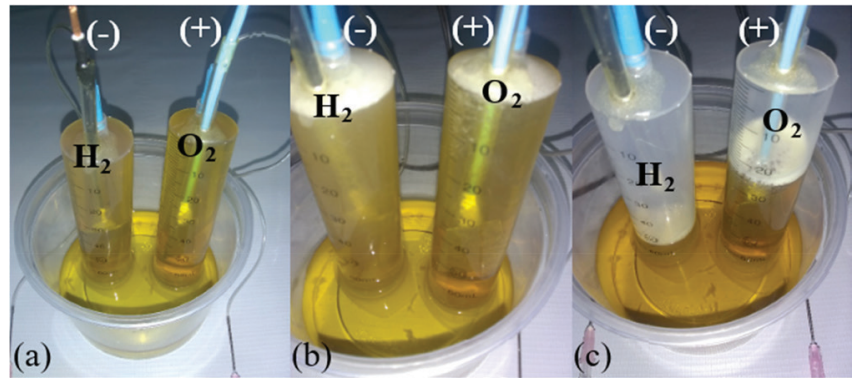

Figura 5. Eletrólise da água utilizando como solução eletrolítica a mistura de NaOH 1,0 mol $\mathrm{L}^{-1}$ com extrato de feijão preto. (a) Início da eletrólise; (b) após 1 minuto de eletrólise; (c) após 5 minutos de eletrólise

da eletrólise da água na célula eletrolítica contendo a mistura $\mathrm{NaOH}$ $1,0 \mathrm{~mol} \mathrm{~L}^{-1}$ com extrato de feijão preto, o que facilita o entendimento das semirreações eletroquímicas de produção dos gases hidrogênio e oxigênio. Novamente o sistema foi mantido aberto e o volume do gás hidrogênio produzido foi o dobro do volume do gás oxigênio, em concordância com a estequiometria da reação para formação da água.

Assim como foi descrito no item anterior, conhecer as semirreações que acontecem no ânodo e no cátodo da célula eletrolítica e relacioná-las com os respectivos potenciais nas condições padrão é importante para definir se a reação eletroquímica será espontânea ou não espontânea. Considerando-se a produção dos gases hidrogênio e oxigênio em solução básica, mostrada nas Figuras 6(c) e (d), pode-se escrever as equações químicas (4) e (5).

O potencial aplicado nos eletrodos imersos na solução eletrolítica favoreceu a ocorrência da reação não espontânea de decomposição da água. No polo negativo (cátodo) iniciou-se a semirreação de desprendimento de hidrogênio, equação química (4), e no polo positivo (ânodo) a semirreação de desprendimento de oxigênio, equação química (5), e a reação global, equação química (6). Detalhes das semirreações eletroquímicas nas condições padrão (1 bar, $1 \mathrm{~mol} \mathrm{~L}^{-1}$ e 298,15 K) em solução básica encontram-se no texto e nas Tabelas 1S, 2S e 3S do Material Suplementar.

cátodo: $4 \mathrm{H}_{2} \mathrm{O}_{(l)}+4 e^{-} \rightarrow 2 \mathrm{H}_{2(\mathrm{~g})}+4 \mathrm{OH}_{(a q)}^{-}$

ânodo: $4 \mathrm{OH}_{(a q)}^{-} \rightarrow \mathrm{O}_{2(g)}+2 \mathrm{H}_{2} \mathrm{O}_{(l)}+4 e^{-}$

reação global: $2 \mathrm{H}_{2} \mathrm{O}_{(\mathrm{l})} \rightarrow \mathrm{O}_{2(\mathrm{~g})}+2 \mathrm{H}_{2(\mathrm{~g})}$

\section{Kit B - célula a combustível}

Consumo dos gases hidrogênio e oxigênio em solução ácida para a produção de energia elétrica

O funcionamento da célula a combustível acontece de maneira inversa ao funcionamento da célula eletrolítica, ou seja, a energia química é convertida em energia elétrica. O trabalho elétrico produzido pela célula a combustível é mantido por meio da injeção dos gases hidrogênio no ânodo (polo negativo) e oxigênio no cátodo (polo 

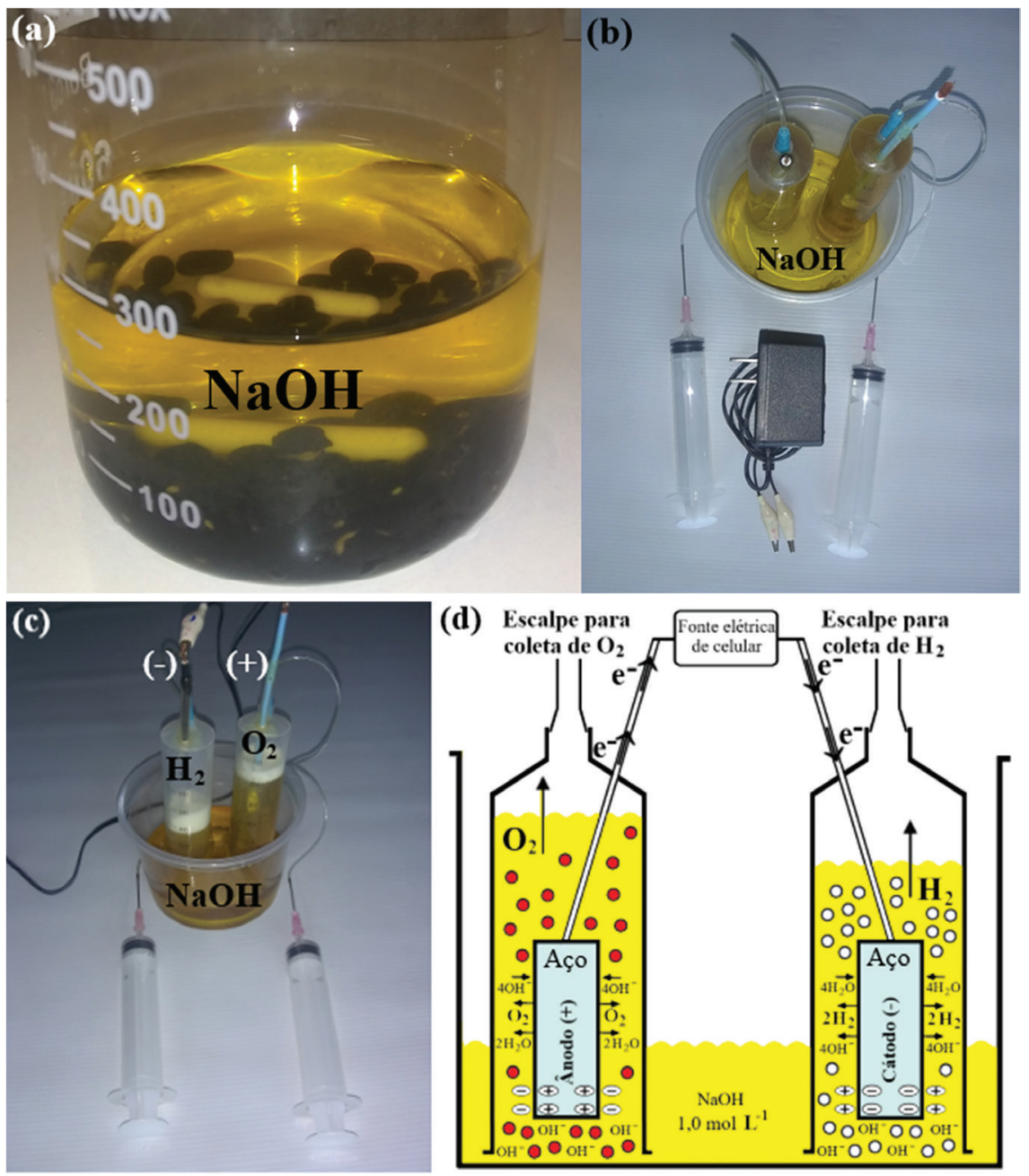

Figura 6. (a) Mistura da solução eletrolítica de $\mathrm{NaOH} \mathrm{1,0} \mathrm{mol} L^{-1}$ com feijão preto para extração das antocianinas; (b) preenchimento das seringas com a

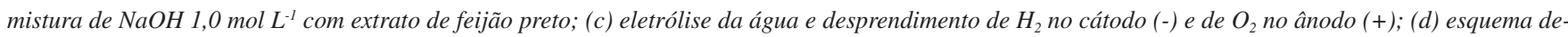
talhando as espécies envolvidas na eletrólise da água em solução básica, $\mathrm{NaOH} \mathrm{1,0} \mathrm{mol} \mathrm{L^{-1 }}$

positivo). Uma célula a combustível operando com gás hidrogênio puro na geração de eletricidade tem como principal produto da reação a água, eliminando totalmente a emissão de poluentes e gases de efeito estufa. Utilizar o excedente de eletricidade gerada por meio de fontes renováveis, como o vento, o sol e a água, para produzir gás hidrogênio, poderá viabilizar a redução dos custos do funcionamento da célula a combustível. Nesse trabalho foi necessário utilizar a associação em série de duas células a combustível para aumentar o potencial e colocar em funcionamento um relógio digital de $1,5 \mathrm{~V} .^{43}$ Para facilitar a compreensão da associação em série usando duas células a combustível, arranjou-se duas pilhas comuns associadas em série, destacando-se os polos positivo e negativo para analogia com a célula a combustível, ver Figura 7.

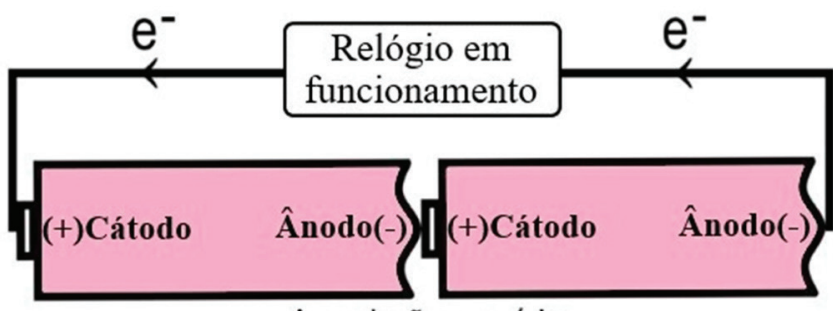

Associação em série

Figura 7. Combinação dos polos positivo e negativo numa associação em série necessária para o aumento do potencial total
As soluções coloridas com extrato de feijão preto apresentam um efeito visual para despertar a atenção dos estudantes. As semirreações de oxidação do $\mathrm{H}_{2}$ e de redução do $\mathrm{O}_{2}$ são silenciosas, não evidenciaram nenhuma mudança de cor ou liberação de bolhas, mas o funcionamento do relógio comprovou o fluxo de corrente elétrica. A montagem do experimento e o seu funcionamento podem despertar a curiosidade e o interesse de estudantes, facilitando a compreensão das reações eletroquímicas envolvidas e do conteúdo aplicado.

A Figura 8(a) apresenta duas células a combustível em solução de $\mathrm{H}_{2} \mathrm{SO}_{4}$ associadas em série. $\mathrm{O}$ gás $\mathrm{H}_{2}$ foi injetado no ânodo (polo negativo) de cada célula a combustível e o gás $\mathrm{O}_{2}$ foi injetado no cátodo (polo positivo) de cada célula a combustível. Controlou-se os volumes dos gases para manter a tripla interface, platina-eletrólitogases, região onde ocorrem a oxidação do $\mathrm{H}_{2}$ e a redução do $\mathrm{O}_{2} \cdot{ }^{44}$ Mediu-se o potencial gerado em cada célula a combustível e também pelas duas células associadas em série, utilizando-se um multímetro digital com alta resistência interna, para não interferir nas medidas de potencial. Os valores dos potenciais medidos situaram-se em torno de $+0,73 \mathrm{~V}$ para cada célula a combustível individual, e em torno de $+1,46 \mathrm{~V}$ para as células a combustível associadas em série; foram realizados vários experimentos. $\mathrm{O}$ valor do potencial medido para a célula a combustível individual foi inferior ao calculado usando os valores dos potenciais padrão de redução das semirreações, estando relacionado com o efeito do potencial ôhmico e do sobrepotencial da célula, conforme apresentado no Material Suplementar. ${ }^{45} \mathrm{O}$ 
relógio digital funcionou normalmente com as células a combustível associadas em série, sendo que o valor do potencial praticamente não apresentou alteração após 8 horas de funcionamento. Tem-se que a conexão do relógio fechou o circuito elétrico e possibilitou o fluxo de elétrons do ânodo (polo negativo) para o cátodo (polo positivo) e, consequentemente, o consumo dos gases reagentes $\mathrm{H}_{2}$ e $\mathrm{O}_{2}$. O consumo dos gases foi muito pequeno, não sendo possível observar alteração de volume nas seringas usadas para acomodar o cátodo e o ânodo após 8 horas de experimento. O funcionamento da célula a combustível acontecerá até atingir o equilíbrio eletroquímico, onde a velocidade com que as espécies reagentes $\mathrm{H}_{2}$ e $\mathrm{O}_{2}$ se combinam é igual velocidade com que o produto $\mathrm{H}_{2} \mathrm{O}$ se decompõe, e o valor do seu potencial alcançará $0 \mathrm{~V}$ e a corrente $0 \mathrm{~A}$.

O esquema apresentado na Figura 8(b) destaca as espécies químicas envolvidas nas semirreações de uma célula a combustível em solução ácida. Os eletrodos confeccionados na forma de espiral aumentaram a superfície da platina na tripla interface, platinaeletrólito-gases, região onde ocorrem as semirreações eletroquímicas, favorecendo a oxidação do $\mathrm{H}_{2}$ e a redução do $\mathrm{O}_{2}{ }^{44}$ A geração de eletricidade envolveu, concomitantemente, a oxidação do gás hidrogênio no ânodo (polo negativo) e a redução do gás oxigênio no cátodo (polo positivo)

Na semirreação de oxidação em solução ácida, para cada duas moléculas do gás hidrogênio ionizadas, formam-se quatro íons hidrogênio $\left(\mathrm{H}^{+}\right)$e quatro elétrons são transferidos, para a redução do gás oxigênio. Os elétrons migram do ânodo para o cátodo, equação química (7). Na semirreação de redução, cada molécula do gás oxigênio consome quatro elétrons, dois elétrons para cada átomo de oxigênio, os quais reagem com os quatro íons hidrogênio e formamse duas moléculas de água, equação química (8). A semirreação de oxidação acontece simultaneamente à semirreação de redução, o que resulta na reação global, equação química (9). O desencadeamento das semirreações de oxidação e de redução dá origem a um fluxo de corrente elétrica na célula a combustível. O menor valor do potencial de redução nas condições padrão (1 bar, 1 mol L-1 e 298,15 K) para o íon hidrogênio $(0,00 \mathrm{~V})$, em comparação com o valor do potencial de redução nas condições padrão para o gás oxigênio $(+1,23 \mathrm{~V})$, indica a espontaneidade das semirreações de oxidaçãoredução. Mais detalhes das semirreações eletroquímicas nas condições padrão em solução ácida encontram-se no texto e nas Tabelas 1S e 4S do Material Suplementar. ânodo: $2 H_{2(g)} \rightarrow 4 H_{(a q)}^{+}+4 e^{-}$

cátodo: $\mathrm{O}_{2(\mathrm{~g})}+4 \mathrm{H}^{+}{ }_{(a q)}+4 e^{-} \rightarrow 2 \mathrm{H}_{2} \mathrm{O}_{(l)}$

reação global: $2 \mathrm{H}_{2(g)}+\mathrm{O}_{2(g)} \rightarrow 2 \mathrm{H}_{2} \mathrm{O}_{(l)}$

Consumo dos gases hidrogênio e oxigênio em solução básica para a produção de energia elétrica

A Figura 9(a) apresenta duas células a combustível em solução de $\mathrm{NaOH}$ associadas em série. $\mathrm{O}$ gás $\mathrm{H}_{2}$ foi injetado no ânodo (polo negativo) de cada célula a combustível e o gás $\mathrm{O}_{2}$ foi injetado no cátodo (polo positivo) de cada célula a combustível. Assim como foi feito em solução ácida, controlou-se o volume dos gases para manter a tripla interface. Acompanhou-se o potencial gerado em cada célula a combustível e também pelas duas células associadas em série, utilizando o multímetro digital. Os valores dos potenciais medidos também ficaram abaixo do esperado, em torno de $+0,82 \mathrm{~V}$ para cada célula a combustível, e em torno de $+1,64 \mathrm{~V}$ para as células associadas em série. $\mathrm{O}$ valor do potencial medido para a célula a combustível individual foi inferior ao calculado usando os valores dos potenciais padrão de redução das semirreações, estando relacionado com o efeito do potencial ôhmico e do sobrepotencial da célula, conforme apresentado no Material Suplementar. O relógio digital funcionou normalmente com as células a combustível associadas em série, sendo que o valor do potencial praticamente não apresentou alteração após 8 horas de funcionamento. Tem-se que a conexão do relógio fechou o circuito elétrico e possibilitou o fluxo de elétrons do ânodo (polo negativo) para o cátodo (polo positivo) e, consequentemente, o consumo dos gases reagentes $\mathrm{H}_{2}$ e $\mathrm{O}_{2}$. Em solução básica, o consumo dos gases também foi muito pequeno após 8 horas de experimento, não sendo possível observar alteração de volume nas seringas usadas para acomodar o cátodo e o ânodo. O funcionamento da célula a combustível será mantido até atingir o equilíbrio eletroquímico, onde a velocidade com que as espécies reagentes $\mathrm{H}_{2}$ e $\mathrm{O}_{2}$ se combinam é igual a velocidade com que o produto $\mathrm{H}_{2} \mathrm{O}$ se decompõe, nesse momento o potencial da célula a combustível é igual a $0 \mathrm{~V}$ e a corrente atinge $0 \mathrm{~A}$.

$\mathrm{O}$ extrato de feijão preto melhorou a visibilidade do experimento e o controle do volume dos gases necessários para manter a tripla interface. O esquema apresentado na Figura 9(b) destaca as espécies químicas envolvidas nas semirreações de uma célula a combustível em solução básica. Assim como foi mostrado em solução ácida, as semirreações eletroquímicas também dependem da adsorção dos
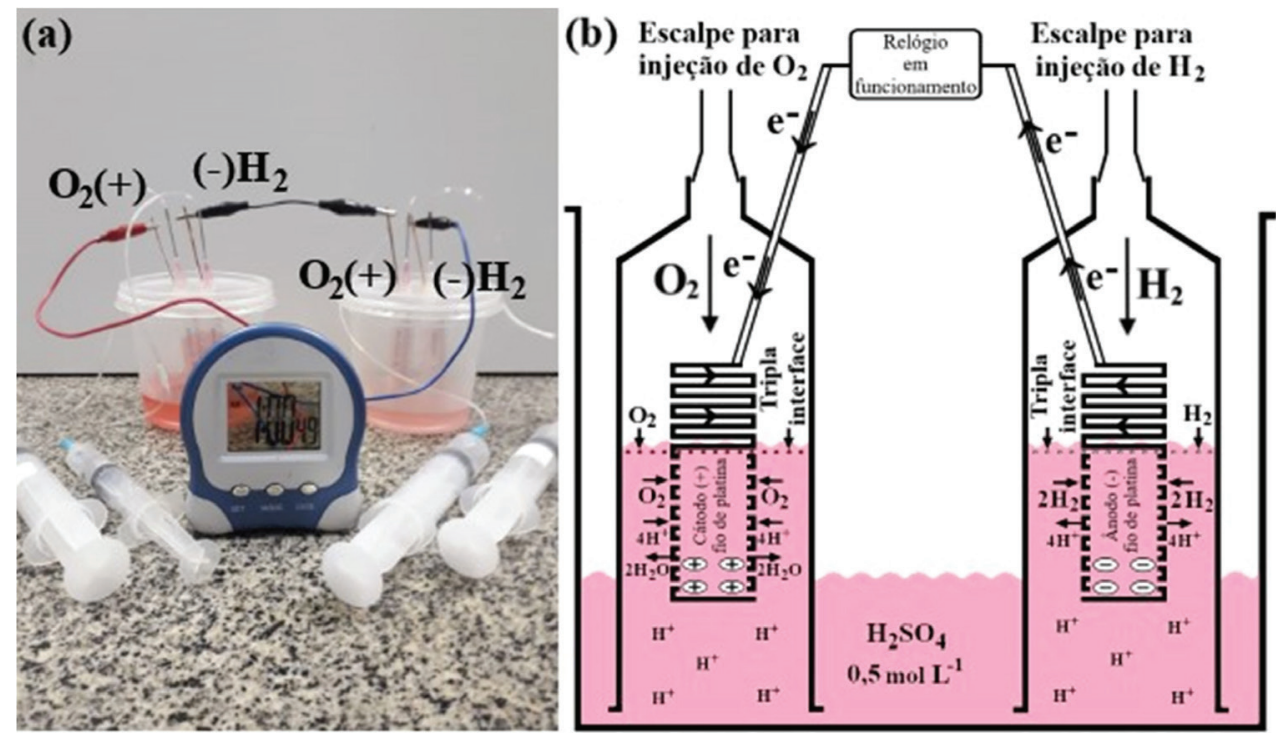

Figura 8. (a) Células a combustível associadas em série e funcionamento do relógio digital; (b) esquema simplificado do funcionamento da célula a combustível em solução ácida, $\mathrm{H}_{2} \mathrm{SO}_{4} \mathrm{O}, 5 \mathrm{~mol} \mathrm{~L} \mathrm{~L}^{-1}$ 

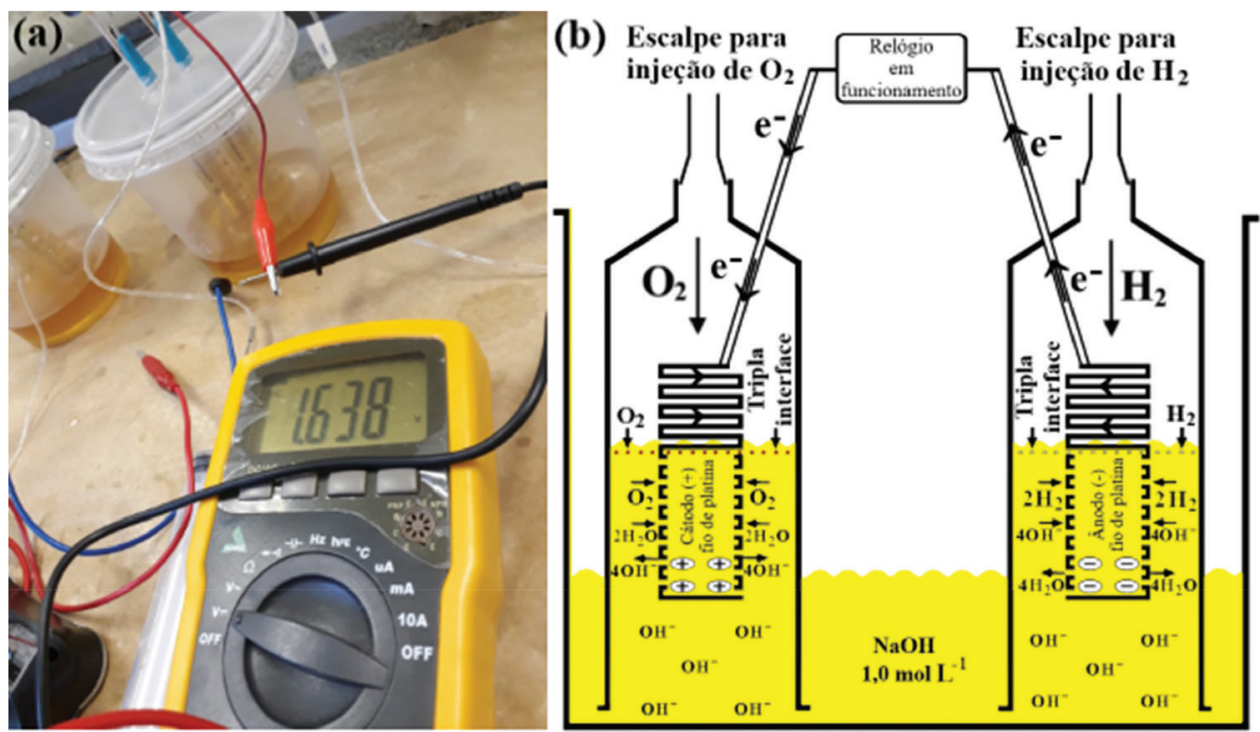

Figura 9. (a) Medida do potencial de duas células a combustível associadas em série; (b) esquema simplificado do funcionamento da célula a combustível em solução básica, $\mathrm{NaOH} \mathrm{1,0} \mathrm{mol} \mathrm{L}^{-1}$

gases na superfície da platina, para posterior dissociação catalítica das moléculas de $\mathrm{H}_{2}$ e $\mathrm{O}_{2}{ }^{25,46,47}$

Na semirreação de oxidação em solução básica, para cada duas moléculas do gás hidrogênio oxidadas, formam-se quatro íons hidrogênio $\left(\mathrm{H}^{+}\right)$, que reagem com quatro íons hidroxila $\left(\mathrm{OH}^{-}\right)$da solução básica, formando-se quatro moléculas de água, e transferindo quatro elétrons para a redução do gás oxigênio. Os elétrons migram do ânodo para o cátodo, equação química (10). Na semirreação de redução, cada molécula do gás oxigênio consome quatro elétrons, dois elétrons para cada átomo de oxigênio, os quais reagem com duas moléculas de água, e formam-se quatro íons hidroxila, equação química (11). A semirreação de oxidação acontece simultaneamente à semirreação de redução, o que resulta na reação global, equação química (12). O desencadeamento das semirreações de oxidação e de redução dá origem a um fluxo de corrente elétrica na célula a combustível. O menor valor do potencial de redução nas condições padrão (1 bar, $1 \mathrm{~mol} \mathrm{~L}^{-1}$ e $298,15 \mathrm{~K}$ ) para a água $(-0,83 \mathrm{~V})$, em comparação com o valor do potencial de redução nas condições padrão para o gás oxigênio $(+0,40 \mathrm{~V})$, indica a tendência de espontaneidade das semirreações de oxidação e redução. Mais detalhes das semirreações eletroquímicas nas condições padrão em solução básica encontram-se no texto e nas Tabelas $1 \mathrm{~S}$ e $5 \mathrm{~S}$ do Material Suplementar.

ânodo: $2 \mathrm{H}_{2(g)}+4 \mathrm{OH}_{(a q)}^{-} \rightarrow 4 \mathrm{H}_{2} \mathrm{O}_{(l)}+4 e^{-}$

cátodo: $\mathrm{O}_{2(g)}+2 \mathrm{H}_{2} \mathrm{O}_{(l)}+4 e^{-} \rightarrow 4 \mathrm{OH}_{(a q)}^{-}$

reação global: $2 \mathrm{H}_{2(g)}+\mathrm{O}_{2(g)} \rightarrow 2 \mathrm{H}_{2} \mathrm{O}_{(l)}$

Os experimentos visam facilitar o entendimento de fenômenos relacionados com as reações eletroquímicas. O baixo custo e a simplicidade da maior parte do material utilizado nos experimentos são apropriados para a replicação dos kits e sua utilização nas diversas condições de infraestrutura das instituições de ensino básico ou superior. A proposta do trabalho também é importante para o desenvolvimento da metodologia científica dos estudantes. $\mathrm{O}$ envolvimento dos estudantes e do professor do ensino básico ou superior na confecção das células eletrolítica e a combustível, utilizando material alternativo de fácil acesso, é muito importante para o processo de ensino-aprendizagem de conceitos relacionados à eletroquímica. A comprovação da corrente elétrica gerada com as semirreações de oxidação e de redução, por meio do funcionamento de um relógio digital ilustra a relevância do tema no que tange à produção de energia alternativa limpa, criando possibilidades para além do uso de fontes de energia não renováveis.

É importante relatar o envolvimento dos estudantes de iniciação científica do curso de Licenciatura em Química e do professor do ensino básico em todas as etapas do trabalho. Os estudantes desenvolveram a percepção integral do projeto, incorporando uma aprendizagem relevante. Os ajustes experimentais e as discussões do conteúdo de eletroquímica resultaram em melhores protótipos e roteiros para uso em sala de aula no ensino médio ou superior. A oportunidade do professor para cursar o mestrado proporcionou uma valorização do profissional do ensino básico, oportunizando a melhoria da qualidade do ensino básico e, consequentemente, daquele estudante que pretende uma formação em nível superior. Numa análise preliminar realizada após aplicação dos experimentos em duas turmas do $2^{\circ}$ ano do ensino médio, o professor mestrando relatou o entusiasmo dos seus estudantes com a execução dos experimentos, sendo uma oportunidade rara. Eles se comportaram incrédulos com as observações visuais realizadas a partir dos experimentos.

\section{CONCLUSÃO}

Um aspecto importante a considerar a respeito das novas tecnologias de baterias e de células a combustível é o armazenamento de energia elétrica sob a forma de energia eletroquímica.

Os kits alternativos de baixo custo facilitam a exploração experimental dos conceitos de eletroquímica, úteis para a explicação e ilustração dos conceitos relacionados com célula eletrolítica (eletrólise da água), bem como com célula a combustível (célula galvânica).

O kit A ilustrou a conversão da energia elétrica em energia química e o kit $\mathrm{B}$ a reação inversa, conversão da energia química em energia elétrica.

A utilização do kit A, célula eletrolítica, possibilitou explorar as semirreações eletroquímicas não espontâneas catódicas (produção de $\mathrm{H}_{2}$ ) e anódicas (produção de $\mathrm{O}_{2}$ ) em soluções ácida e básica.

A utilização do kit $\mathrm{B}$, célula a combustível, favoreceu a exploração das semirreações eletroquímicas espontâneas anódicas (consumo de $\mathrm{H}_{2}$ ) e catódicas (consumo de $\mathrm{O}_{2}$ ) em soluções ácida e básica.

$\mathrm{O}$ uso do extrato de feijão preto, um indicador alternativo de $\mathrm{pH}$, deixou o experimento colorido, facilitando observar a formação 
de bolhas dos gases $\mathrm{H}_{2}$ e $\mathrm{O}_{2}$ na superfície dos eletrodos e realizar a leitura dos volumes.

$\mathrm{O}$ arranjo experimental simples, de produção e manipulação dos gases, dispensa o uso de instrumentação específica.

A relação do professor do ensino básico com os estudantes da Química criou oportunidades para troca de experiências, contribuindo com uma formação continuada qualificada do professor, bem como com a formação inicial dos licenciandos em química.

O professor pode suscitar, a partir dos dois experimentos realizados, as questões ambientais, sociais, econômicas e éticas, que permeiam o cotidiano das pessoas.

O experimento representa uma ótima oportunidade de aplicação no curso de graduação como também no ensino básico, como ferramenta facilitadora do processo de ensino-aprendizagem de conceitos relacionados com a eletroquímica.

\section{MATERIAL SUPLEMENTAR}

O detalhamento das equações químicas e matemáticas estão disponíveis em http://quimicanova.sbq.org.br, na forma de arquivo PDF, com acesso livre.

\section{AGRADECIMENTOS}

O presente trabalho foi realizado com apoio da Coordenação de Aperfeiçoamento de Pessoal de Nível Superior - Brasil (CAPES) - Código de Financiamento 001. M. M. S. Silveira agradece às escolas E. E. Prof. Antônio da Silva (Carneirinho/MG) e E. E. Dom Pedro II (União de Minas/MG). Os autores agradecem ao Programa de Mestrado Profissional em Química em Rede Nacional (PROFQUI/UFTM), à RQ-MG/FAPEMIG (REDE-113/10; CEXRED-00010-14), o Prof. Dr. N. C. Coimbra (FMRP/USP), pela doação do fio de platina e ao Comitê Especial de Acompanhamento do COVID-19 na UFTM, que autorizou o uso do laboratório durante a pandemia.

\section{REFERÊNCIAS}

1. Piccolino, M.; Bresadola, M.; Trends Neurosci. 2002, 25, 51.

2. Piccolino, M.; Bresadola, M.; Shocking Frogs: Galvani, Volta, and the Electric Origins of Neuroscience, Oxford University Press: United States of America, 2013.

3. Coimbra, M. A.; Libardi, W.; Morelli, M. R.; Cerâmica 2004, 50, 300.

4. Daniell, J. F.; Philos. Trans. R. Soc. London 1836, 126, 107.

5. http://boletim.sbq.org.br/noticias/2019/n3428.php, acessada em Agosto 2020.

6. Appleby, A. J.; J. Power Sources 1990, 29, 3.

7. Grove, W. R.; Philos. Mag. J. Sci. 1839, 14, 127.

8. Crowe, B. J.; Fuel Cells - A Survey, National Aeronautics and Space Administration: Washington, D.C., 1973.

9. Santos, V. P.; Rev. Virtual Quim. 2016, 8, 634.

10. Villullas, H. M.; Ticianelli, E. A.; González, E. R.; Quim. Nova Esc. 2002, 15, 28

11. Vijh, A. K.; J. Chem. Educ. 1970, 47, 680.

12. http://www2.aneel.gov.br/aplicacoes/atlas/pdf/03-Energia_Solar(3).pdf, acessada em agosto 2020.

13. Vianello, R. L.; Alves, A. R.; Meteorologia Básica e Aplicações, $2^{\mathrm{a}}$ ed., Editora UFV: Viçosa, 2013.

14. http://www2.aneel.gov.br/aplicacoes/atlas/pdf/06-energia_eolica(3).pdf, acessada em agosto 2020.
15. http://www.cresesb.cepel.br/publicacoes/download/atlas_eolico/ Atlas\%20do\%20Potencial\%20Eolico\%20Brasileiro.pdf, acessada em agosto 2020.

16. http://www2.aneel.gov.br/aplicacoes/atlas/pdf/04-Energia_Hidraulica(2). pdf, acessada em agosto 2020.

17. http://www2.aneel.gov.br/arquivos/PDF/atlas_par2_cap3.pdf, acessada em agosto 2020

18. Goldemberg, J.; São Paulo em Perspectiva 2000, 14, 91.

19. Silva, Y. F. F. C.; Bortoni, E. C.; Revista Brasileira de Energia 2016, 22 , 48.

20. Agostinho, S. M. L.; Jaimes, R. F. V. V.; Vairolette, L.; Santos, I. V. S.; Quim. Nova 2019, 42, 453.

21. Santos, D. M. F.; Sequeira, C. A. C.; Figueiredo, J. L.; Quim. Nova 2013, 36, 1176.

22. Silva, I. F.; Silva, A. J. P.; Rev. Virtual Quim. 2019, 11, 937.

23. Klein, S. G.; Braibante; M. E. F.; Quim. Nova Esc. 2017, 39, 35.

24. Santos, T. N. P.; Batista, C. H.; Oliveira, A. P. C.; Cruz, M. C. P.; Quim. Nova Esc. 2018, 40, 258.

25. Wendt, H.; Götz, M.; Linardi, M.; Quim. Nova 2000, 23, 538.

26. Braibante, M. E. F.; Oliveira, F. V.; Klein, S. G.; $34^{\circ}$ Encontro de Debates sobre o Ensino de Química (EDEQ), http://www.unisc.br/site/ edeq/, acessada em junho 2020.

27. Wartha, E. J.; Reis, M. S.; Silveira, M. P.; Guzzi Filho, N. J.; Jesus, R. M.; Quim. Nova Esc. 2007, 26, 17.

28. Sanjuan, M. E. C.; Santos, C. V.; Maia, J. O.; Silva, A. F. A.; Wartha, E. J.; Quim. Nova Esc. 2009, 31, 190.

29. Santos, E.; Santos, G. F.; Silva, V. M.; Melo, R. P. A.; Lopes, F. L. G.; Sci. Plena 2013, 9, 1.

30. Sartori, E. R.; Batista, E. F.; Fatibello-Filho, O.; Quim. Nova Esc. 2008, 30,61 .

31. Fragal, V. H.; Maeda, S. M.; Palma, E. P.; Buzatto, M. B. P.; Rodrigues, M. A.; Silva, E. L.; Quim. Nova Esc. 2011, 33, 216.

32. Bocchi, N.; Ferracin, L. C.; Biaggio, S. R.; Quim. Nova Esc. 2000, 11, 3.

33. Finazzi, G. A.; Martins, C. N.; Capelato, M. D.; Ferreira, L. H.; Quim. Nova 2016, 39, 12.

34. Sartori, E. R.; Santos, V. B.; Trench, A. B.; Fatibello-Filho, O.; Quim. Nova Esc. 2013, 35, 107.

35. Barreto, B. S. J.; Batista, C. H.; Cruz, M. C. P.; Quim. Nova Esc. 2017, 39,52 .

36. Niaz, M.; Chacón, E. A.; J. Sci. Educ. Technol. 2003, 12, 129.

37. Soares, M. H. F. B.; Cavalheiro, E. T. G.; Antunes, P. A.; Quim. Nova 2001, 24, 408.

38. Roffia, S.; Concialini, V.; Paradisi, C.; Lambert, J.; J. Chem. Educ. 1988, 65,725 .

39. Ticianelli, E. A.; Gonzalez, E. R.; Eletroquímica, $2^{\text {a }}$ ed., Edusp: São Paulo, 2013

40. Gouveia-Matos, J. A. M.; Quim. Nova Esc. 1999, 10, 6.

41. Okumura, F.; Soares, M. H. F. B.; Cavalheiro, E. T. G.; Quim. Nova 2002, 25, 680 .

42. Janeiro, P.; Brett, A. M. O.; Electroanalysis 2007, 19, 1779.

43. Diniz, B. P.; Alves, A. S.; Lemes, L. C.; Silva, L. A.; Alves, V. A.; Quim. Nova Esc. 2020, 42, 77.

44. Weissbart, J.; J. Chem. Educ. 1961, 38, 267.

45. Skoog, D. A.; West, D. M.; Holler, F. J.; Crouch, S. R.; Fundamentos de Química Analítica, Thomson: São Paulo, 2006.

46. Carrette, L.; Friedrich, K. A.; Stimming, U.; Fuel Cells 2001, 1, 5.

47. An, L.; Zhao, T.; Yan, X.; Zhou, X.; Tan, P.; Sci. Bull. 2015, 60, 55. 